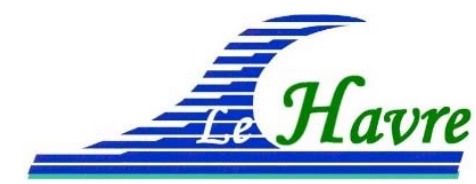

XVI ${ }^{\text {èmes }}$ Journées Nationales Génie Côtier - Génie Civil

Le Havre, 2020

DOI:10.5150/jngcgc.2020.072 (c) Editions Paralia CFL

disponible en ligne - http://www.paralia.fr - available online

\title{
Sediment-based fired brick strength optimization A discussion on different approaches
}

\author{
Mazhar HUSSAIN ${ }^{1,2}$, Daniel LEVACHER ${ }^{1}$, Nathalie LEBLANC ${ }^{\text {, }}$ \\ Hafida ZMAMOU ${ }^{2}$, Irini DJERAN-MAIGRE ${ }^{3}$, Andry RAZAKAMANANTSOA ${ }^{4}$
}

1. Normandie Université, Unicaen, UMR 6143 CNRS - M2C, 24 rue des Tilleuls, 14000 Caen, France. mazhar.hussain@unicaen.fr ; daniel.levacher@unicaen.fr

2. UniLaSalle, Univ.Artois, EA7519 - Transformations \& Agro-ressources, Normandie Université, 76130 Mont Saint Aignan, France.

3. Université Lyon, INSA Lyon, GEOMAS, 69621 Villeurbanne, France.

4. Université Gustave Eiffel, Département GERS, 44344 Bouguenais, France.

\begin{abstract}
:
Sustainable sediment management is a global issue due to dredging of rivers and river mouths for both navigability and flood protection needs. Previous studies on sediments beneficial uses have shown that essentially the targeted materials relate to roads and ceramics (bricks, tiles). For sustainable management, these recovery sectors impose the minimization of transport and the restriction of the use of binders with a high carbon footprint and addition materials in mixtures (renewable resources). Ceramics for construction appears to constitute a direct recovery method for dredged sediments. Even if it requires adequate water content for manufacturing, it does not require any addition of material. However, mixtures of sediments can be operated to improve the chemical composition before firing (optimization). Waste as aggregates (foundry and pickling sand, silica fume, crushed brick, ...) can be incorporated in such mixtures (ecofriendly recovery). Different approaches are available to ensure the feasibility (composition and implementation) of producing ceramic materials for construction (bricks, tiles, pottery). In practice, they are mainly based on industrial methodological approaches (diagrams by Winkler, Augustinik, Sembenelli). These diagrams were drawn up from well-identified non-renewable resources (clays, sands) from mines and quarries. For dredged sediments i.e. mixtures of clay, silty particles and fine sands, other approaches should be defined based on these practical approaches. They can be defined considering the nature and mineralogy of clays, or based on specific properties of the sediment or else resulting from statistical methods. These latter are considered as coupled approaches more efficient for a laboratory investigation. This type of coupled approach combined with an appropriate experimental method, provides a guide for any feasibility study of raw or fired sedimentbased bricks. A complete but simple methodology for recovering sediments as ceramic construction material is outlined.
\end{abstract}




\section{Thème 6 - Gestion durable des zones littorales et estuariennes}

\section{Keywords:}

Sediment, Characterization, Beneficial uses, Ceramics material, Methodological approach, Sustainable management

\section{Introduction}

Many investigations have been conducted on utilization of waste materials in fired bricks as sediments. Contaminated sediments were first concerned by manufacturing bricks in which a part of clay/sand was substituted by sediments. By this way, contaminants were eliminated, inert or chemically transformed and the feasibility of producing depends mainly on the quality of bricks obtained and the environmental safety in their use. Recent reviews report beneficial uses with calcined sediments such as lightweight aggregates or as binder in concrete but limited studies were cited on the use of raw sediments i.e. without chemical pretreatment, in fired bricks (RAUT et al., 2011; ZHANG, 2013; MONTEIRO \& VIEIRA, 2014; CAPPUYNS et al., 2015; EAN et al., 2018; JUNAKOVA \& JUNAK, 2019). No chemical pretreatment is not desirable making the brick production sustainable and environment-friendly even if this process consumes energy. But the substitution of natural resources i.e. clay/sand by waste as sediments should constitute an eco-friendly solution to the sediment management by insuring the renewability of primary resources and eliminating a waste.

Some research works are found in literature where sediments (marine, fluvial, dam, alluvial deposits) were introduced as a large part or totally in the raw material for building ceramics production (bricks, tiles). A summary of these works conducted on uncontaminated or weakly contaminated sediments is presented in Table 1. In this list, work in which the sediments have been previously chemically treated is not listed for environmental reasons. An important technical point should be mentioned, it concerns the dewatering of dredged sediments. Even if dewatering techniques for sediments are improving (BOULLOSA ALLARIZ, 2018), dewatering of sediments remains an obstacle to any potential beneficial uses; for most of the applications identified for the manufacture of bricks (table 1), the sediments are naturally dehydrated. Considering an adequate ratio of clay/sand, sediments can be used as raw materials in producing bricks as long as the mechanical and environmental performance complies with the standards.

The manufacture of bricks generally requires the preparation of a homogeneous mixture shaped by molding or extrusion, then progressively dried for limiting cracks before firing the shaped blocks between $800-1100^{\circ} \mathrm{C}$. However, the feasibility of fired bricks from dredged sediments needs to be demonstrated and to do so, different approaches are proposed. They are mainly based on the study of sediment properties, the determination of which is important. In this paper, these different approaches are explained and applied to sediments of the Usumacinta River (Mexico) for the manufacture of bricks fired at a temperature of $850^{\circ} \mathrm{C}$. The challenge is to provide a simple methodology for reusing sediments as an alternative source of raw materials for brick production. 


\section{XVIèmes Journées Nationales Génie Côtier - Génie Civil \\ Le Havre 2020}

Table 1. Studies on production of bricks made from low or uncontaminated sediments.

\begin{tabular}{|c|c|c|c|}
\hline References & Sediment origin & Sediment rate (\%) & Others (\%) \\
\hline Anger (2014) & Dam sediments, (France) & $80-100$ & Kaolinite \\
\hline Baruzzo et al (2006) & Marine sediment & - & - \\
\hline Bathnagar \& Goel (2002) & Alluvial deposits, Indo-Gange (India) & & \\
\hline $\begin{array}{l}\text { Ben Allal et al (2011); } \\
\text { Frar et al (2014) }\end{array}$ & Port sediment, Larache \& Tanger, Morroco & $0-70$ & Clay \\
\hline Benkadja et al (2013) & Dam sediment, K'sob, Algeria & $0-65$ & Dune sand \\
\hline Boulingui et al (2015) & - & - & - \\
\hline Chiang et al (2008) & Dam sediment, Shi-Men (Taiwan) & $80-100$ & Clay \\
\hline Haurine (2016) & Dam sediments (France) & $70-100$ & Fine sand, crushed tiles \\
\hline Labiod et al (2018) & Bouhanifa dam sediment, (Algeria) & 100 & - \\
\hline Liang \&Li (2015) & Dam sediment & - & Gypsum \\
\hline Marouf (2018), Marouf et al (2018) & Bouhanifa dam sediment, (Algeria) & - & - \\
\hline Nedloussi et al (2019) & Gargar dam sediment, (Algeria) & $80-100$ & Sand \\
\hline Remini (2006) & Dam sediments, (Algeria) & $0-100$ & Yellow clay \\
\hline Romero et al (2009) & Santander Harbour (Spain) & 100 & - \\
\hline Samara et al (2019) & Dampremy River, Charleroi, (Belgium) & 100 & Low PI \\
\hline Tangprasert et al (2015) & Lumsai River, Bangkok (Thailand) & $80-100$ & Rice husks \\
\hline Torres et al (2009) & Ria de Aveiro River,(Portugal) & $5-10$ & Low to plastic clays \\
\hline Wei et. al (2014a) & Harbour sediment & - & Steel slag \\
\hline Wei et. al (2014b) & - & - & - \\
\hline Xu et al (2014) & River sediment & $50-80$ & - \\
\hline $\begin{array}{l}\text { Yeboah et al (2011); } \\
\text { Mezencevova et al (2012) }\end{array}$ & Savannah Harbour, (USA) & $\begin{array}{l}100 \\
50\end{array}$ & - Clay (50) \\
\hline Zhang et al (2016) & Lake sediment, Nanjing, (China) & - & Cinder, sewage sludge \\
\hline
\end{tabular}

Table 1. (continued).

\begin{tabular}{|c|c|c|c|c|c|}
\hline References & Firing temperature $\left({ }^{\circ} \mathrm{C}\right)$ & UCS (MPa) & WSC (\%) & Porosity (\%) & Bulk density $\left(\mathrm{g} / \mathrm{cm}^{3}\right)$ \\
\hline Anger (2014) & $800-\underline{880-1100}-1150$ & $7.5-10$ & $20-31$ & $41-51$ & $1.36-1.52$ \\
\hline Baruzzo et al (2006) & & - & - & - & - \\
\hline Bathnagar \& Goel (2002) & $700-1100$ & & & & \\
\hline $\begin{array}{l}\text { Ben Allal et al (2011); } \\
\text { Frar et al (2014) }\end{array}$ & $\underline{920}$ & $33-6.8$ & $10-33$ & $18-45$ & $1.81-1.37$ \\
\hline Benkadja et al (2013) & 800 & - & 55 & - & - \\
\hline Boulingui et al (2015) & & - & - & - & - \\
\hline Chiang et al (2008) & $\underline{1050-1100}-1150$ & - & - & - & - \\
\hline Haurine (2016) & $950-1100$ & $5-50$ & - & - & - \\
\hline Labiod et al (2018) & & $5-9$ & - & - & - \\
\hline Liang \&Li (2015) & $\underline{1100}$ & - & - & - & - \\
\hline Marouf (2018), Marouf et al (2018) & $\underline{850}-1050$ & 21 & $30-40$ & - & - \\
\hline Nedloussi et al (2019) & $600-900$ & $28-46$ & - & - & - \\
\hline Remini (2006) & $\underline{900}$ & $10-40$ & $6-20$ & $12-24$ & $1.4-1.9$ \\
\hline Romero et al (2009) & $900-1200$ & 34 & $4-22$ & $12-38$ & $1.60-2.45$ \\
\hline Samara et al (2019) & $\underline{1000}$ & 36 & 7.5 & 15.4 & - \\
\hline Tangprasert et al (2015) & 700 & $1.9-9$ & $17.8-29$ & - & $1.13-1.57$ \\
\hline Torres et al (2009) & $950-1100$ & $7.5-35$ & $3.5-15.5$ & - & - \\
\hline Wei et. al (2014a) & $950-\underline{1100}$ & - & - & - & - \\
\hline Wei et. al (2014b) & $\underline{1100}$ & - & - & - & - \\
\hline Xu et al (2014) & $\underline{1100}$ & - & - & - & - \\
\hline $\begin{array}{l}\text { Yeboah et al (2011); } \\
\text { Mezencevova et al (2012) }\end{array}$ & $\begin{array}{l}900-1100 \\
900-1000 \\
\end{array}$ & $\begin{array}{l}8.3-11.7 \\
29.4\end{array}$ & & - & - \\
\hline Zhang et al (2016) & - & - & - & - & - \\
\hline
\end{tabular}

Note: Sediment rate: Sediment proportion in mixture; Others: other components in mixture; UCS: Unconfined compressive strength; WSC: Water sorption capacity (24h); PI: Plasticity Index; 880-1100: optimal values of temperature; All references in table 1 are available in HUSSAIN (2020). 


\section{Thème 6 - Gestion durable des zones littorales et estuariennes}

\section{Methodology}

2.1 Sediment minimal characterization for brick manufacturing

Sediment characterization is important. Indeed it must allow the comparison of the sediment characteristics with those of the raw materials i.e. natural clay and sand used in the manufacture of bricks. It must be judicious in order to limit the cost of the characterization tests as well. It mainly focuses on physical properties, chemical elemental analyses, mineralogical composition and as suggested in figure 1 (left, in the 3 first columns, red arrows). Environmental assessment is to be conducted if there is evidence of contamination in sediments ( $4^{\text {th }}$ column in figure 1 with green arrows).
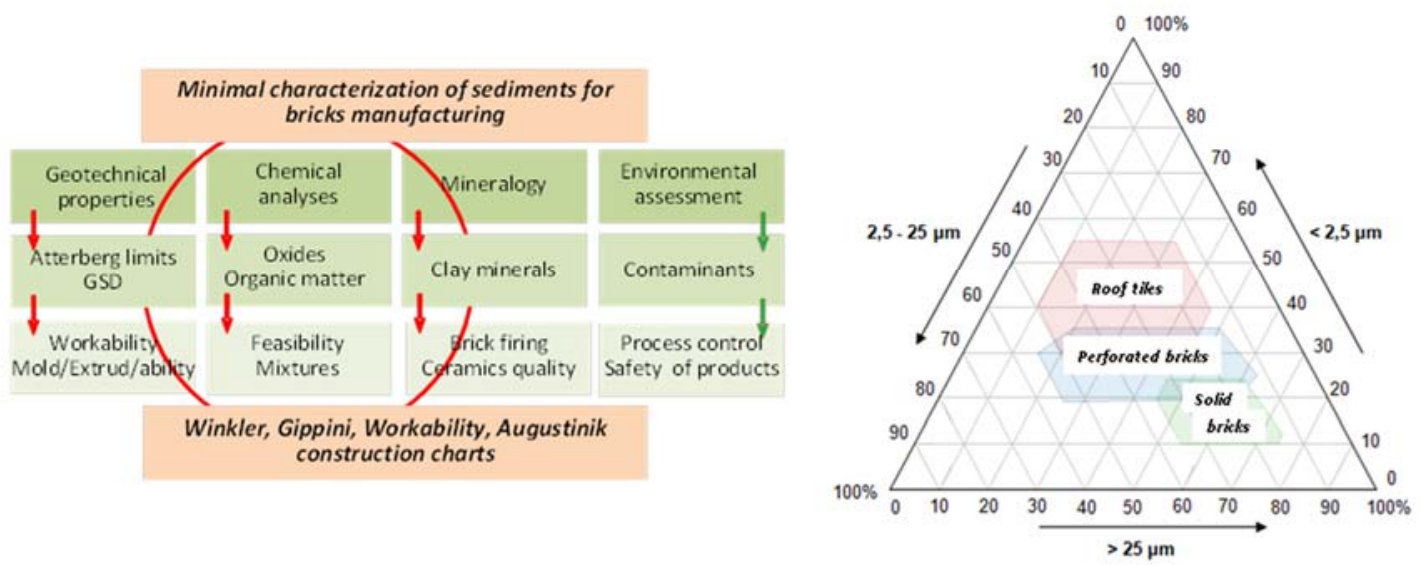

Figure 1. Sediment characterization for brick production feasibility and Winkler chart.

From grain size distribution (GSD), the sediment data is usually plotted in the Winkler's diagram that allows the identification of major zones of sediment-based products according to national standards. These zones (figures $1 \& 2$ ) are more or less detailed for different ceramics products. As can be observed in figure 3 (left diagram), the grain size behavior of the clayey mixtures is suitable for one the 3 types of ceramics.
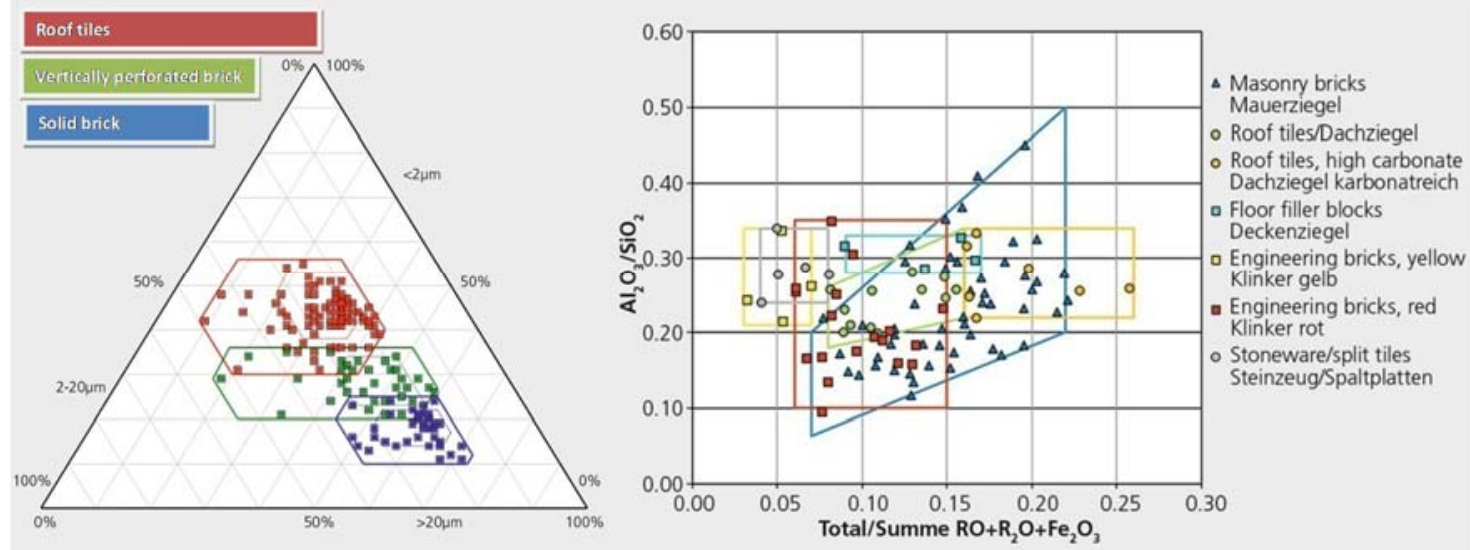

Figure 2. Winkler and Augustinik charts used in brick industry (BTII-ZI, 2015). 


\section{XVİ̀mes Journées Nationales Génie Côtier - Génie Civil \\ Le Havre 2020}

When data near these zones, it is possible to modify mixtures with mineral or waste additions in an eco-friendly brick production. In the framework of an international project, a study on the valorization of sediments in the fired brick production was carried out and led to situate the grain size data in this Winkler diagram (VAL USES, 2017; DJERAN-MAIGRE et al., 2020). As the data were more or less close to the recommended areas, modifications were suggested to improve the suitability of the sediment-based mixes for brick manufacture (YAMAGUCHI, 2018). From chemical analyses mainly with the oxides composition, another diagram allows to define the ability of clayey mixtures for fired ceramics. As shown in figure 3 (right), different zones are proposed for various heavy clay products in a revised Augustinik diagram (BTII-ZI, 2015). As mentioned above, it is possible to adapt mixtures with additions to improve their suitability for brick production; for example many waste additions are reviewed by RAUT \& GOMEZ (2016) for enhancing thermal performance of bricks.

\subsection{Water-sediment mixture workability for brick manufacturing}

The behavior of water-sediment mixture is evaluated using the consistency with Atterberg limits i.e. plasticity tests whatever the manufacturing type (extrusion, molding or handmade). Thus, the qualities of the mixture for a possible (area B, in figure 3 ) or optimal (area A) extrusion can be revealed by the use of the Casagrande diagram adapted to the molding of ceramic pastes according to GIPPINI (1969). Plasticity of sediments is affected by the presence of organic matters and some pollutants, the ratio of clay/sand that causes difficulties in the molding (formation of lumps, laminations and cracking) and drying process (cracks and shrinkage).
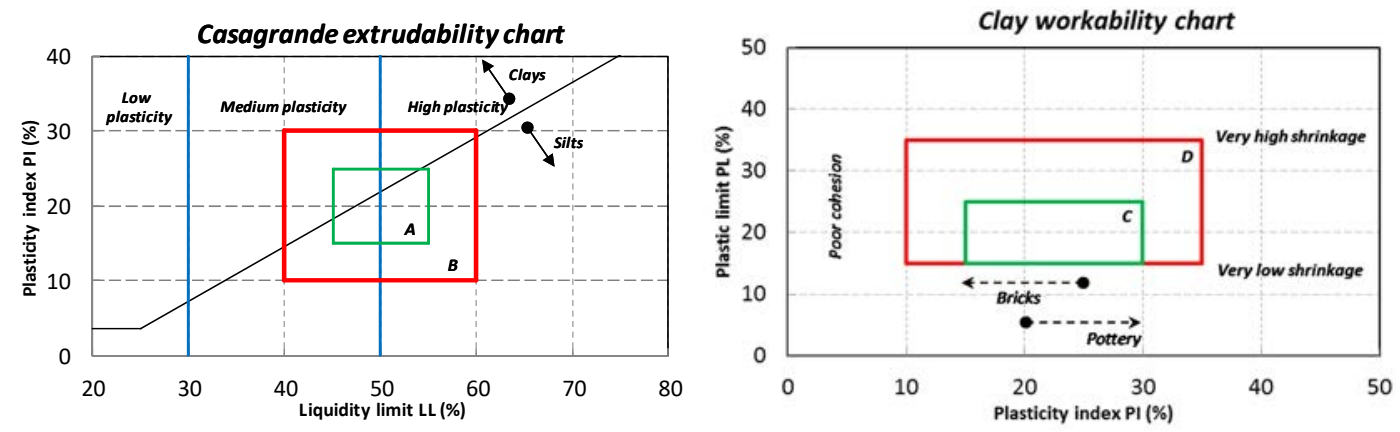

Figure 3. Extrusion/molding and workablity charts for brick raw materials.

Workability chart (BAIN \& HIGHLEY, 1979) defines 2 zones in which the raw material paste i.e. sediment plus water, presents possible (zone D, in figure 3) and optimal (zone C) characteristics for molding and extrusion. Considering crude bricks, it is possible to adapt the same Casagrande extrusion chart by adding a simplified zone (in blue, figure 4) for compressed (CEB), rammed earth blocks (REB) and adobe according to results reported by DELGADO \& GUERRERO (2007). This zone is comprised between the A line of Casagrande and its parallel passing through the origin. $O$. 


\section{Thème 6 - Gestion durable des zones littorales et estuariennes}

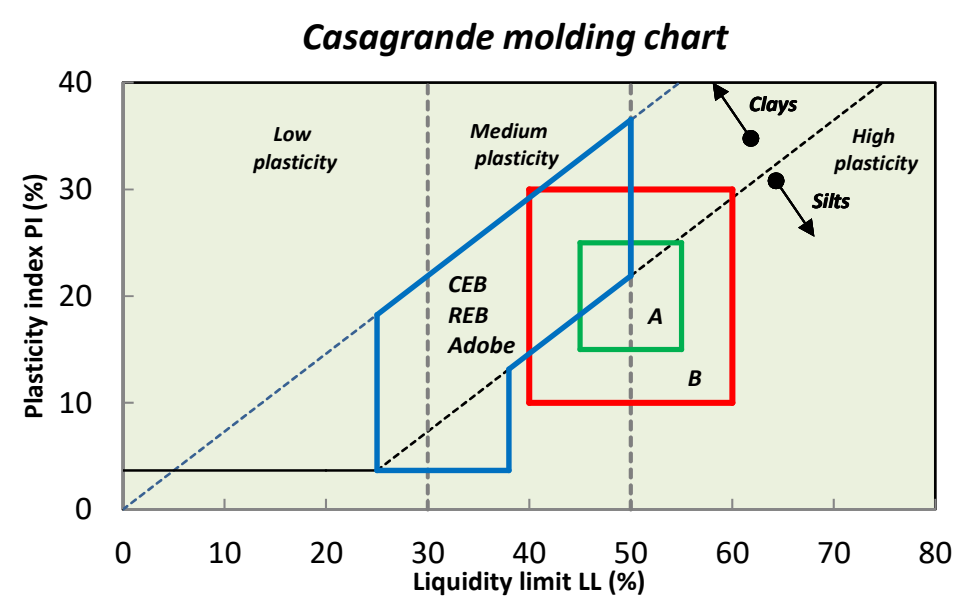

Figure 4. Extrusion/molding chart for crude and fired brick raw materials.

\subsection{Water-sediment content for brick molding}

In practice, a suitable sediment-water mixture is one that can be molded with the minimum amount of water and offers the least amount of shrinkage. This aspect was studied by SEMBENELLI (1966) with the help of the Casagrande diagram on which he defined a range of possible values of water content by graphical representation (figure 5). SEMBENELLI (1966) interpretation about quantity of water need to mix with clayey soil or sediment to make ceramics has significant importance in manufacturing bricks. In figure 5, the point $B$ is the value of shrinkage limit of sediment. Water content needed to mix with sediments ranges between the point $\mathrm{C}$ and $\mathrm{D}$. If the amount of water added to the sediments is very high, the bricks will be deformed easily during molding and huge shrinkage will occur when these bricks are dried and burnt in oven. If quantity of water added is very low, it is difficult to mound the soil mixture into bricks. Hence suitable quantity of water is necessary to make good quality bricks (HUSSAIN, 2020).

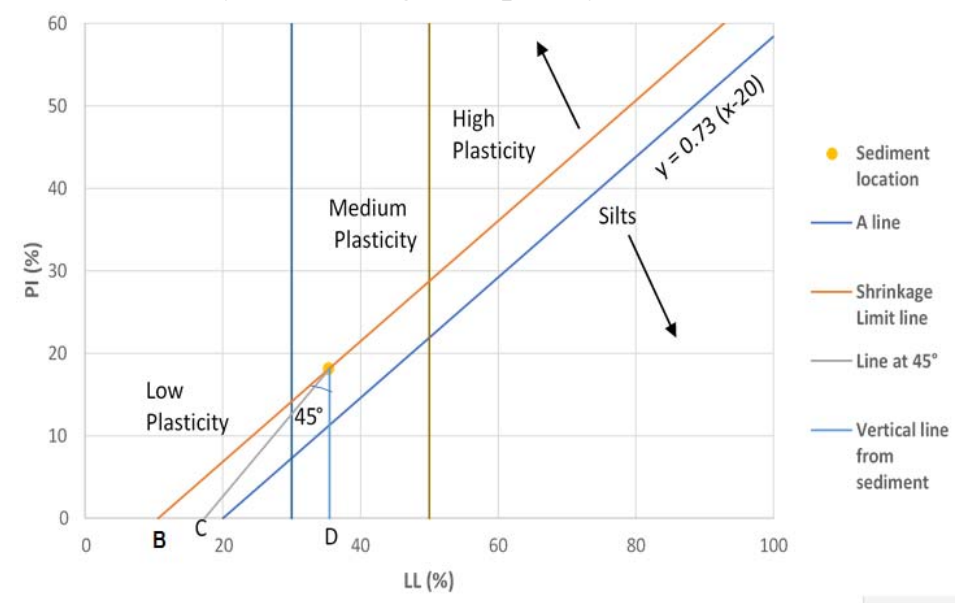

Figure 5. Sembenelli chart for preparing clayey or sediment-based mixtures. 


\section{XVIèmes Journées Nationales Génie Côtier - Génie Civil \\ Le Havre 2020}

\section{Possible approaches for optimizing sediment mixtures in laboratory}

Table 2 explains the methodology followed in the development of brick manufacture from sediments and specifically in a case of study for river sediments (VAL USES, 2017). Usually once the sediments were collected in hermetically sealed barrels at the sampling sites and characterized (figure 1), the construction of the various diagrams showed that it was possible to consider the manufacture of sediment-based bricks in the laboratory (VAL USES, 2017). Although variability in certain characteristics has been observed, it is possible to modify or adapt certain sediment mixtures to improve their properties and finally the quality of brick as reported by YAMAGUCHI (2018).

Table 2. Methodology and strategy used for sediment-based fired bricks optimization.

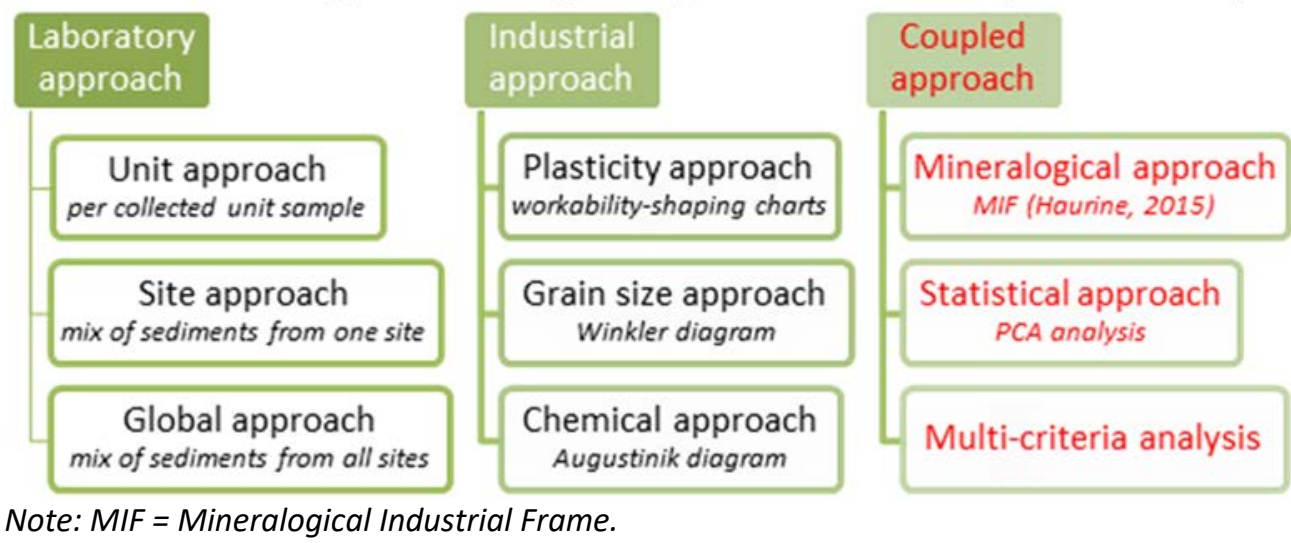

The methodology used consisted in first considering sediments at the unit or site scale: sediment alone, per site and for all sites. Then the following approaches were to consider a more industrial approach based on the use of different diagrams (plasticity, particle size and chemical approaches). The variability in sediment characteristics showed that mixture optimization required a coupled approach with possibly appropriate statistical analysis, e.g., linking mineralogical and other properties (figure 1). These different approaches resulted in the manufacture of fired bricks and the evaluation of physical and mechanical strength properties (HUSSAIN, 2019; 2020).

\section{Experimental methodology applied for sediment-based bricks in laboratory}

\subsection{Sample preparation, molding and firing}

Manufacturing of fired bricks consist of material preparation, molding, drying, firing and testing, see illustration of these stages on table 3. In material preparation, soil selection and choice of water content to make bricks was done. Water content was derived from Sembenelli diagram shown in figure 5. Midpoint between points $\mathrm{C}$ and $\mathrm{D}$ was generally used as water content for all sediments mixtures but adjustments are sometimes necessary due to high clay and sand content respectively. This is followed by mixing of sediments and molding into cubic, prismatic or cylindrical specimens; shapes and dimensions are 


\section{Thème 6 - Gestion durable des zones littorales et estuariennes}

depending on the final application focused, testing standards and the available sediment volume.

Table 3. Steps for manufacturing and controlling sediment-based fired brick samples.
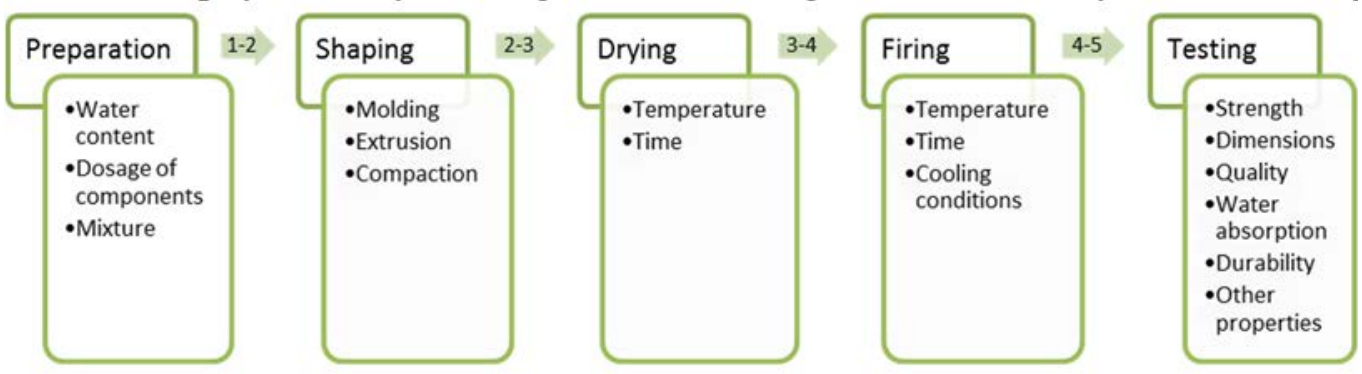

As shown as an example for river sediments (figure 6), cubic samples of size $20 \mathrm{~mm} * 20 \mathrm{~mm} * 20 \mathrm{~mm}$ for compressive strength test and prismatic specimens of $60 \mathrm{~mm} * 15 \mathrm{~mm} * 15 \mathrm{~mm}$ for flexural strength test were prepared. Bricks were dried in oven at $60{ }^{\circ} \mathrm{C}$ for $4-12$ hours to prevent deformation and cracks development and burnt at $850^{\circ} \mathrm{C}$ for six hours (HUSSAIN, 2019; 2020).
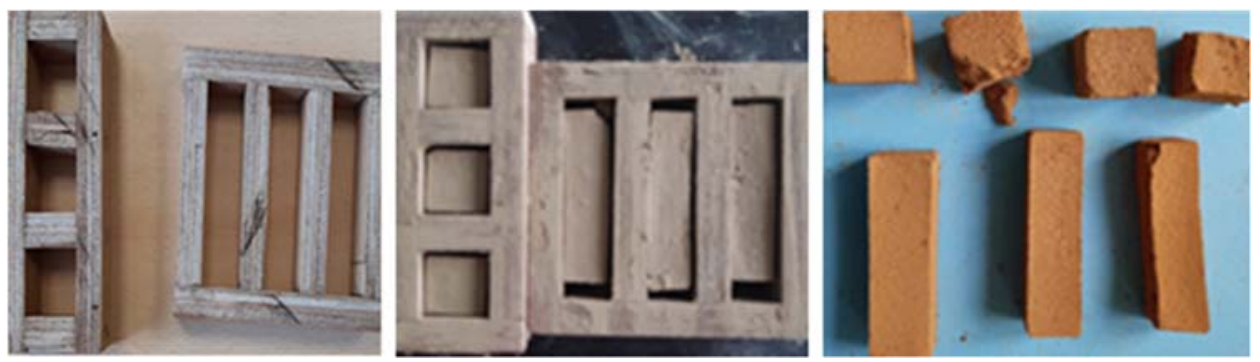

Figure 6. Molds, crude and fired brick samples, (HUSSAIN, 2019).

\subsection{Quality and strength assessment of sediment-based fired brick samples}

It was observed that length and thickness of bricks decreases after firing. Linear shrinkage and bulk density increase at high temperature for most of the bricks made from sediments. At high temperature, clay particles melt and fuse together and fill the voids which decrease porosity and water absorption of bricks. Presence of different minerals (iron, calcium and magnesium oxides) and chemical reactions gives bricks various colours (red, white and dark colour). Presence of quartz and kaolinite gives yellow colour to bricks and transformation of iron minerals into hematite gives reddish colour to bricks (KREIMEYER, 1986). Bricks exhibit dark colour at high temperature. Colour variation for prismatic brick samples made from river sediments at firing temperature of $700{ }^{\circ} \mathrm{C}$ to $1100{ }^{\circ} \mathrm{C}$ is shown in figure 7 . These sediments have clay content $(14.2 \%)$, low carbonate content $(1.9 \%)$, and low organic matter $(3.46 \%)$. Compressive and flexural strength (figure 7) tests were performed on cubic and prismatic samples respectively. 


\section{XVI'̀mes Journées Nationales Génie Côtier - Génie Civil \\ Le Havre 2020}
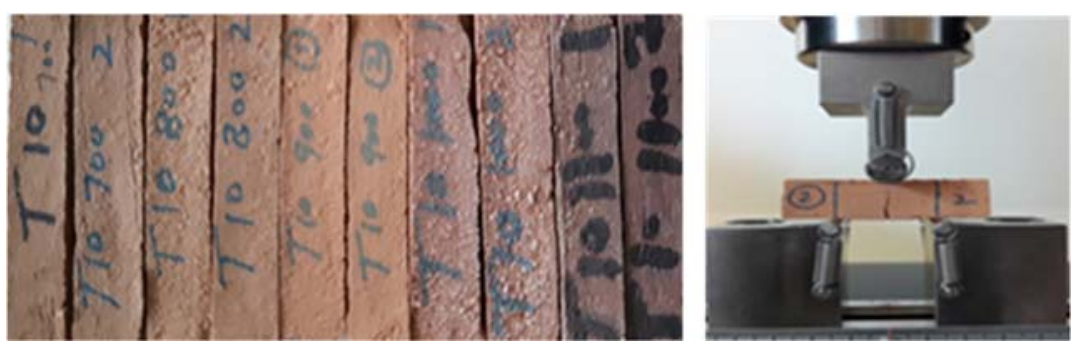

Figure 7. Aspect and range of colors of sediment-based brick samples fired from 700$1100^{\circ} \mathrm{C}$ (left); flexural testing on fired brick sample (right), (HUSSAIN, 2019).

\section{Conclusions and concluding remarks}

The possible use of sediments in the brick production process requires an appropriate characterization. Particle size distribution, plasticity, chemical analyses, mineralogy are all essential for the characterization. Based on their properties, it has been shown that sediments can be used as a primary raw material in the production of fired bricks. Clay/sand ratio and nature of clay and sand influence greatly the partial or total replacement in fired brick. To do so, different approaches are proposed to optimize the sediment mixes in an attempt to reuse $100 \%$ sediment and obtain a better compromise in the quality of the bricks. A coupled approach seems more adapted to carry out an optimization of the mixtures within the same sediment deposit.

Producing sediment-based bricks saves primary and natural resources but also in the case of adjusting the composition of sediment mixtures to include other wastes.

\section{Références bibliographiques}

BAIN J.A., HIGHLEY D.E. (1979). Regional appraisal of clay resources. A challenge to the clay mineralogist. Development on sedimentology, Vol. 27, pp 437-446. https://doi.org/10.1016/S0070-4571(08)70741-6

BOULLOSA ALLARIZ B. (2018). Déshydratation naturelle et mécanisée de sédiments : étude des processus mis en jeu et applications. Thèse de doctorat, Université de Normandie, Unicaen, France, 427p. tel-02292209, version 1

BTII-ZI (2015). Methods of evaluation for raw material suitability and body optimization (Part 2). Technical Paper, Issue6/2015, Brick and Tile Industry International, Ziegelindustrie International.

CAPPUYNS V., DEWEIRT V., ROUSSEAU S. (2015). Dredged sediments as a resource for brick production: Possibilities and barriers from a consumers' perspective. Waste Management, Vol. 38, pp 372-380. https://doi.org/10.1016/j.wasman.2014.12.025

DELGADO M.C.J., GUERRERO I.C. (2007). The selection of soils for unstabilised earth building: A normative review. Construction and Building Materials, Vol. 21 (2), pp 237-251. https://doi.org/10.1016/j.conbuildmat.2005.08.006

DJERAN-MAIGRE I., LEVACHER D., RAZAKAMANANTSOA A.-R., VACHERIE S. (2020). Les sédiments fluviaux de l'Usumacinta et leur valorisation-Usumacinta river 


\section{Thème 6 - Gestion durable des zones littorales et estuariennes}

sediments from Mexico and their valorization, Journées Nationales de Géotechnique et de Géologie de l'Ingénieur 2020, Lyon, 8 p., in press.

EAN L. W., MALEK M. A., MOHAMMED B. S., TANG C.-W., BONG P. X. H. (2018). A Review on characterization of sediments for green bricks production, International Journal of Engineering \& Technology, 7 (4.35), pp 41-47.

GIPPINI E. (1969). Contribution à l'étude des propriétés de moulage des argiles et des mélanges optimaux de matières premières. L’industrie céramique, 619, pp 423-435.

HUSSAIN M. (2019). State of art on valorization of sediments in bio-based materials, Report 2019-12-16-ULS-M2C-MH-001, UniLaSalle-Université de Caen Normandie, 42p. HUSSAIN M. (2020). Valorization of Usumacinta River sediments in bio-based materials. State of art, sediments properties, fired and mud bricks. Report 2020-02-20ULS-M2C-MH-002, UniLaSalle-Université de Caen Normandie, 175 p.

JUNAKOVA N., JUNAK J. (2019). Alternative reuse of bottom sediments in construction materials: overview, IOP Conf. Ser.: Mater. Sci. Eng. 549, 012038, pp 1-6, https://doi.org/10.1088/1757-899X/549/1/012038

KREIMEYER R. (1986). Some notes on the firing colour of clay bricks. Applied Clay Science, 2, pp 175-183. https://doi.org/10.1016/0169-1317(87)90007-X

MONTEIRO S. N., VIEIRA C. M. F. (2014). On the production of fired clay bricks from waste materials: A critical update. Constr. Build. Mater., Vol. 68, pp 599-610, https://doi.org/10.1016/j.conbuildmat.2014.07.006

RAUT S. P., RALEGAONKAR R. V., MANDAVGANE S. A. (2011). Development of sustainable construction material using industrial and agricultural solid waste: A review of waste-create bricks. Constr. Build. Mater., 2011, Vol. 25(10), pp 4037-4442. https://doi.org/10.1016/i.conbuildmat.2011.04.038

RAUT A.N., GOMEZ C.P. (2016). Utilization of waste as a constituent ingredient for enhancing thermal performance of bricks - A review paper. Indian Journal of Science and Technology, Vol 9 (37), 11 p. https://doi.org/10.17485/ijst/2016/v9i37/87082

SEMBENELLI P. (1966). Los limites de Atterberg y su significando en la industria ceramica y ládrillera. Materiales de Construcción Vol. 16, n 124, Octubre, noviembre, diciembre de 1966, pp 43-5, 43-14.

VAL USES (2017). From traditional uses to an integrated valorization of sediments in the Usumacinta river basin - VAL-USES. ANR-17-CE03-0012, https://anr.fr > Project-ANR-17CE03-0012

YAMAGUCHI K. (2018). Consideration of the sustainable utilization of the sediments in Usumacinta River. Master thesis report, Kyoto University-IFSTTAR-Université de Caen-Normandie, $20 \mathrm{p}$.

ZHANG L. (2013). Production of bricks from waste materials - A review. Construction and Building Materials. Vol. 47, pp 643-655. https://doi.org/10.1016/j.conbuildmat.2013.05.043 